\title{
YOUNG
}

Studies in Porto Rican Fungi

Botany
A. M.
1915 
THE UNIVERSITY

OF ILLINOIS

LIBRARY

1915

Y 8 


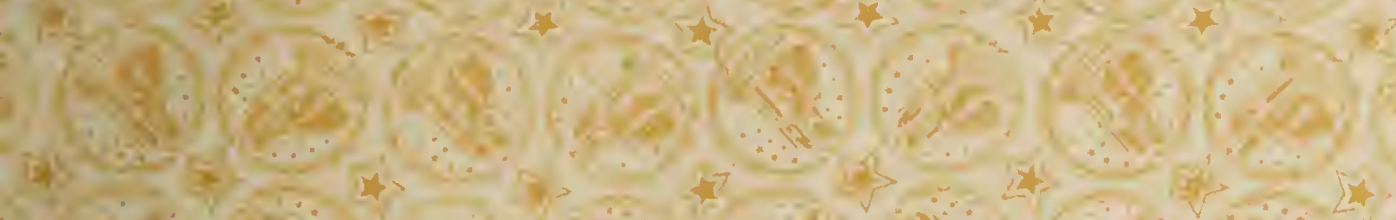
$\cos \theta$
82069
Sines of
हive?

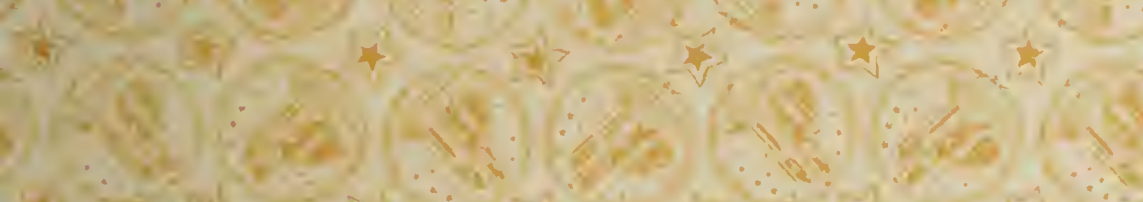
$4,4=0$

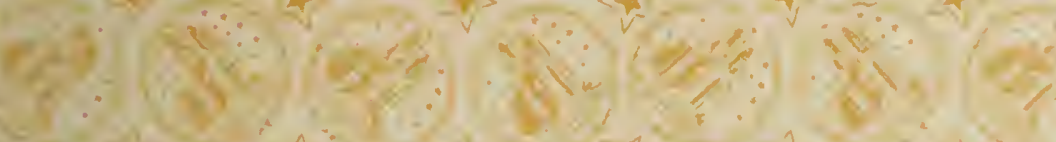

(t)
8.8
S. $1.5(-2)$

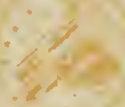
(5) 15 (5) 6$)^{4}(0,1$
is
$\frac{10}{4}$

19

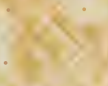

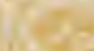

8

andis.

$20 \mathrm{~s}$

$\operatorname{los}^{2}+\frac{1}{2}$
20

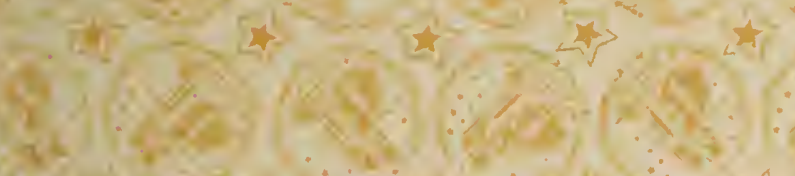

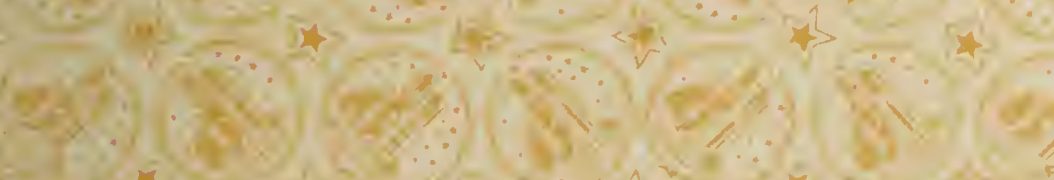

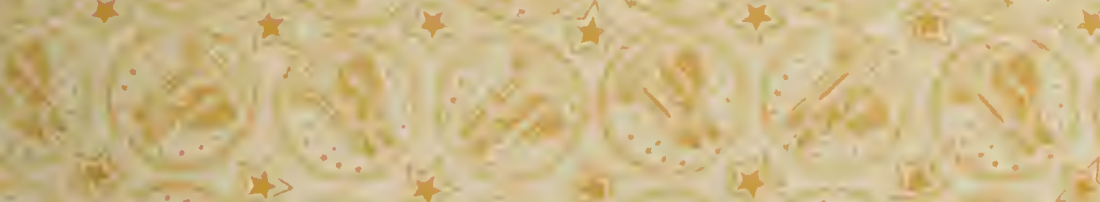

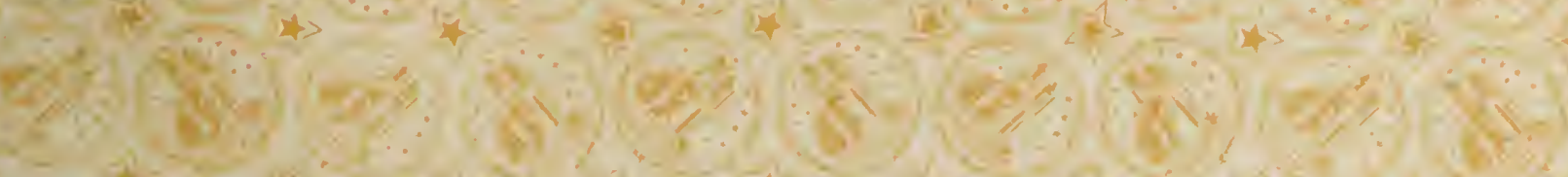

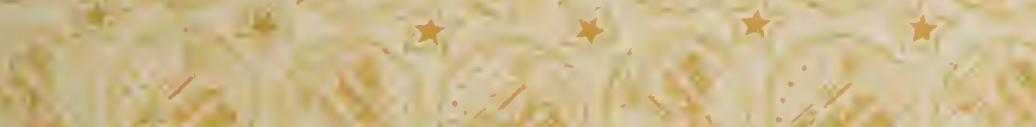

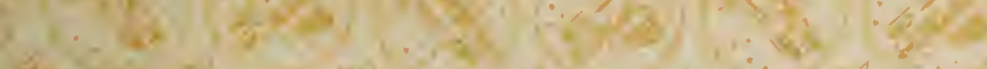

2.

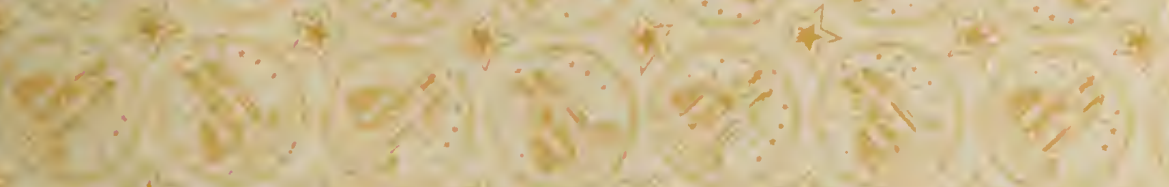
$2^{2}+2$

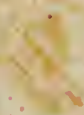
in:
SW.
48
8. $\therefore y=$

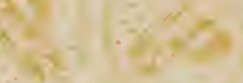

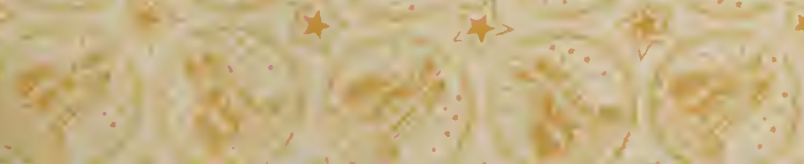

$8 \mathbb{S}^{2}$

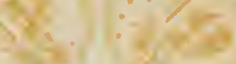

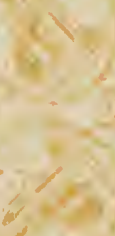

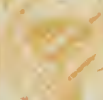

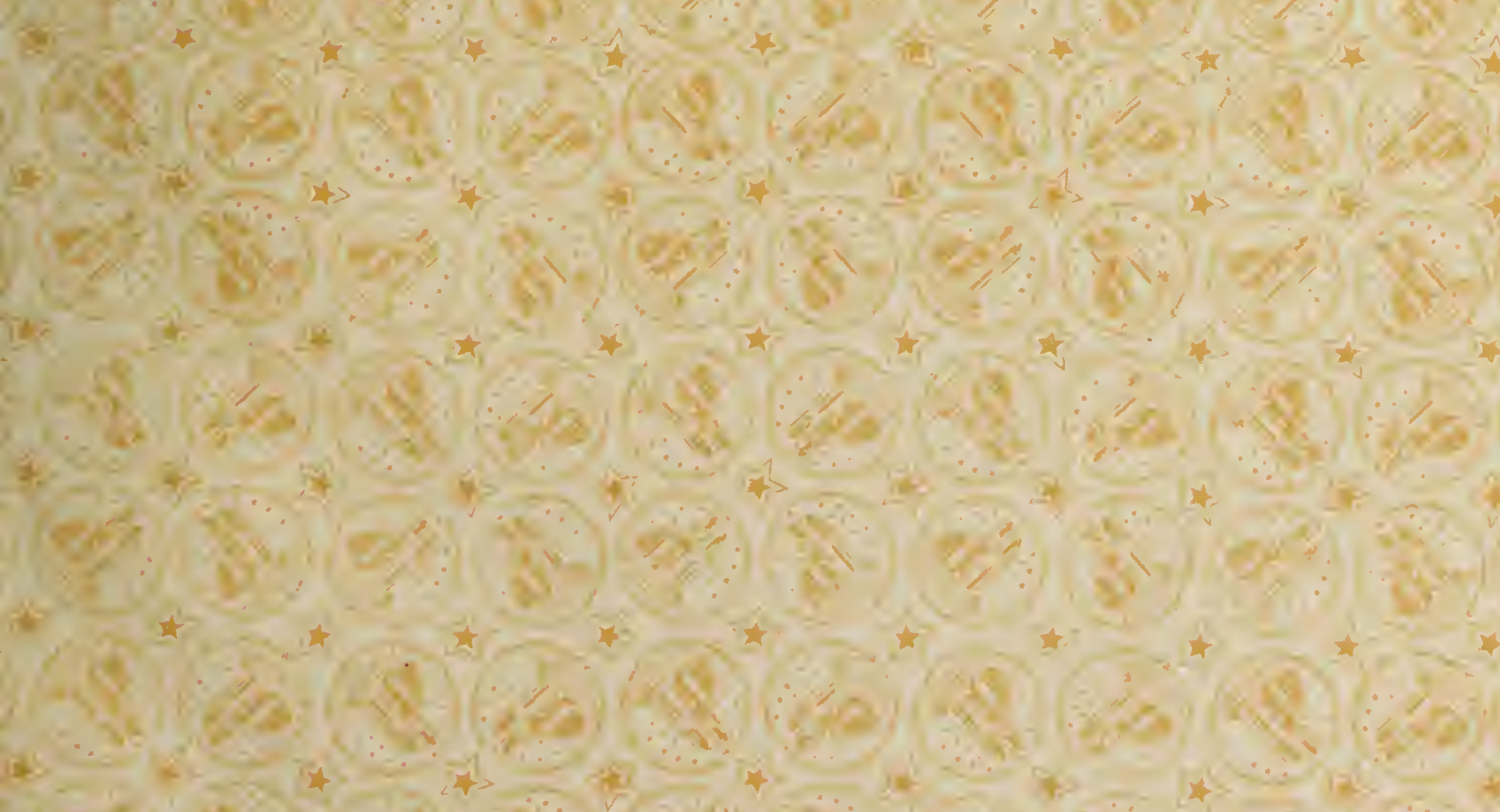

exis 



\section{STUDIES IN PORTO RICAN FUNGI}

BY

ESTHER YOUNG

A. B. Miami University, 1914

THESIS

Submitted in Partial Fulfillment of the Requirements for the

Degree of

MASTER OF ARTS

IN BOTANY

IN

THE GRADUATE SCHOOL

OF THE

UNIVERSITY OF ILLINOIS

1915 
Digitized by the Internet Archive in 2014

http://archive.org/details/studiesinportori00youn 


\section{UN IVERSITY OF ILLINOIS \\ THE GRADUATE SCHOOL}

May 29 190

I HEREBY RECOMMEND THAT THE THESIS PREPARED UNDER MY SUPERVISION BY

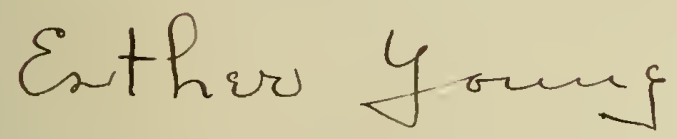

Entitled Studies in Porto Ru'con timgc'

BE ACCEPTED AS FULFILLING THIS PART OF THE REQUIREMENTS FOR THE

Degree of Mastre of Cirts

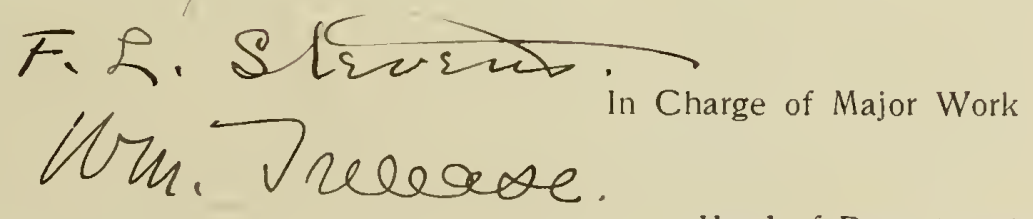

Head of Department

Recommendation concurred in:

Committee

on

Final Examination 

TABLE OF COITERNTS

I Introduction.

Characters and Discussion of the genus Cercospora. ...-I

Characters and Discussion of the genus Phyllosticta..- 2

I Specific Descriptions of Phyllosticta.

Fhyllosticta adianticola sp. nov.; P. sacchari Speg•; P. panici sp. nov.; F. colocasiae Hohnel; P. colocasicola Hohnel; P. cormelinicola sp. nov.; P. coccoloba Li1. \& Ev.; F. momisiana sp. rov.; P. pithecolobii sp. nov.; P. pithecolobii monensis var. nov•; P. divergens Sacc.; F. Euanicensis sp. nov.; F. erythrinicola sp. nov.; P. portoricensis sp. nov.: Pó cissicola. Speg.; F. Eterensii sp. nov.; P. borinquensis sp. nov.; P. bixina sp. nov.; P. eupatoricola Kab. \& Bub.; P. eugeniae sp. nov.; P. guareae P. Henn.; P. araliana sp.nov.; F. sechii sp. nov.; P. glaucibpora Delacr.; P. Ipomoeac Ell. \& Kell.; F. pandanicola sp nov.

III Specific Descriptions of Cercospora.

Cercospora amaryllidis Ell. \& Ev.; C. hydropiperis (Thum) Speg.; C. lepidii Peck; C. phyllitidis Hum.; C. cajani F. Henn.; C. hibisci Tracy \& Earle; C. conspicua Farle; C. bloxami B. \& Br. emend.; C. portoricensis Earle; C. vaginae Kreuger; C. mucunae Syd.; C. rosicola (Pass.) Sacc.; C. Cassavae Ell. \& Ev.; C. denaissima Speg.; C. chamaecristae Ell.\& Kell. 

C. borinquensis sp. nov.; C. guanicensiz sp. nov.;

c. stevensii sp. nov.; C. bradburyac sp. nov.; $C$.

maricaoensis sp. nov.; C. malachrae sp. nov.--11- 16 



\section{INTRODUCTION}

During the years 1912 and 1913, Dr. F. L. Stevens made extensive collections of parasitic fungi in Porto Rico. Desecheo and Mona Islands. The collection was placed in the herbarium of the University of Illinois, and I have made use of this material in my studies, working chiefly on the two genera Phyllosticta and Cercospora.

The genus Cercospora of about 700 species, contains many important parasites chiefly causing leaf-spotting. The spots are variable in size and color, often bordered by a dark margin with a sordid white center due to the fungal hyphae which penetrate into the leaf. The apots are usually definite though in some instances indefinite or even lacking. If conditions are favorable, growth is abundant and the spots may become hoary or the leaf may be covered with a smokybrown mass, due to the large number of spores. The fruiting bodies are conidia which are borne on the ends of hyphae or conidiophores. These vary in number and size. They may be simple or branched, and are brown in color. They are often abruptly bent at the point of spore production, and thus conldial scars are left. Conidiophores are usually fasciculate, but they may arise singly from the stomata of the leaf. As a rule, they vary in length and septation with age. The conidia are hyaline, usually several-septate and vary in size and shape. They are elongate, clavate, fusoid or straight, and sometimes attenuate at the end farthest from the conidiophore. Each cell of the conidium is capable of germination, and very often spores falling on the leaf produce germ tubes and infest the host through the stomata. Very few cross inoculations have been made, and little is really known concerning the limitations of the species. When the host plants 

are different, minor variations in size, color, septation, etc. of the conidia and conidiophores, or in macroscopic appearances of the spots are generally employed in distinguighing species.

The genus Phyllosticta is very large, comprising nearly 1200 species, only a few of which have been determined by comparison or cultural studies. These forms produce leaf-spots which may be circular, angular, or indefinite. The genus differs from Phoma in that it inhabits only the leaves, while the latter may spread over the fruit, twigs or stems; also in that Phoma never produces a definite spot. The leaf-blotch caused by Phyllosticta is due to a weakening, or killing of the leaf-tisaue by the mycelium which spreads throughout the leaf. When conditions are favorable, the spots develop rapidly and the greater part of the leaf from the margin to the mid-rib may become involved. Sometimes the spots are brow, giving the appearance of sunburn, or againthey may be of a yellowioh color, or sordidwhite. The center of the spot often falls out, and eventually when affected to guch an extent that they can no longer function, the leaves fall, thus weakening the vitality of the host. Instead of being borne on naked conidiophores 3.8 in Cercospora, the conidia are produced in pycnidia. These are usually on the upper surface of the leaf, though sometimes below. They may occur singly or in clusters, and may be immersed, erumpent, or superficial. When immeraed, a beak pierces the epidermis, thus facilitating the escape of conidia. The pycnidia are lenticular to globose, usually brown or black, and opening by a pore or ostiole. The conidia are hyaline, usually ovate to elliptical, though sometimes spherical, and they vary in length from 2 to $60 \mathrm{mu}$. The perfect stage of this form is known in but few cases.

It has been the custom to designate as new those forms which 

have never been reported on the particular host, or an any genus of the same family, and which are distinct from any form on a related host. In working over some fifty different forms, I have found fifteen which are in this sense new species. However I hesitate to describe these new forms as Phyllosticta, rather than Phoma, since I believe there is no tenable distinction between these two genera. They are alike in the character of conidia and pycnidia, which seem to me to be the most important characters. The general nature of the spot cannot serve as a distinguishing feature since they are both definite and indefinite on the leaves, nor does it seem justifiable to make the location of infection the basis for distinguishing genera. The final designation, however, of these and related forms must be made after a monographic study of the genera has been completed.

\section{SPECIPIC DESCRIPTIONS OF PHYLIOSTICIA.}

\section{Phyllostictia adianticola sp. nov.}

Spots amphigenous, ovate to ovate-cuneiform, often acute at the basal end, 4-12 mm. in diam., older portions aghen-gray, 1-2 X $2-4 \mathrm{~mm}$. , border yellowish-brom; pycnidia fet, epiphyllous, brom, spherical, 72-120 mu, in diam., ostiole distinct, dark-bordered, 12 mu. in diam.; conidia hyaline, ovate, slightly pointed at one end, $4.8-7.2 \times 2.4 \mathrm{mu}$.

On leaves of Adiantum tenerum Sw. jn Porto Rico: Manati, 4299 (type); Utuado, 4588; QuebradiJ.103, 5000.

Apparcntly very common in all parts of the island of porto Rico, though with very sparse pycnidia. This species is accompanied by a species of Nelanomma. 
On Saccharum in Porto Rico. Juana Diaz, 102.

3. Phyllosticta panici sp. nov.

Spots indefinite, diffuse; pycnidia few, often in clusters, eoiphyllous, dark-orow to black, spherical, $72-144 \mathrm{mu}$ in diam., mycelium a brow mass of septate hyphae; conidia hyaline, pvate, 4.3 $-9.6 \times 3.6 \mathrm{mu}$.

On leaves of Panicum maximum Jacq. in Porto Rico: Coamo, 830 (type): Nartin Pena, Helzer $37 \%$.

\section{Phyllosticta Colocasiae H8hnel,}

Sitz.-ber. Akad. Wis3. Wien. 116: 142. 1907.

On Dieffenbachia in Porto Rico: Monte de Oro near Cayey, 5670.

\section{Phyllosticta Colocasicola Hohnel.}

Sitz.-ber. Akad. Wiss. Wien, 116: 142. 1907.

On Colocasia in Porto Rico: Cagua, 504.

6. Phyllosticta commelinicola sp. nov.

Spots indefinite, diffuse; pycnidia subepidermal, numerous on the upper surface, light-brown, $96-168 \mathrm{mu}$. in diam., ostiole distinct, dark-bordered, 2.4 - $48 \mathrm{mu}$ in diam.; conidia hyaline, ovate, $9.6-14.4 \times 4.8-7.2 \mathrm{mu}$.

On leaves of Cormelina nuduflora $L$, in Porto Rico: Hormigueros 214 (type).

7. Phyllosticta Coccoloba Ellis \& Ev. Ann. Rep. Wissouri Bot. Gard.9: 118. 1898. In our specimens, the spots and spores differ somewhat from those of the description, the spots being larger and reddish-purple 

becoming gray in the center. The spores are shorter, measuring 2.4 $4.8 \times 2.4 \mathrm{snu}$.

\section{Phyllosticta momisiana sp. nov.}

Spots diffuse, sordid-white to yellow, margin indefinite, mostly affecting the apical and marginal portions of the leaf; pycnidia numerous, epiphyllous, dark-brown, spherical, 48 - $60 \mathrm{mu}$ in dian., ostiole distinct; conidia hyaline, ovate, $4.8-7.2 \times 2.4 \mathrm{mu}$. On leaves of liomisia iguanaea $(\mathrm{Jacq}$.$) R. \& S. in Porto Rico:$ Coamo, 334 (type).

9. Phyl.10sticta pithecolobii sp. nov.

Spots amphigenous, rsubcircular to ovate, 5 - $10 \mathrm{~mm}$. in diam., yellowish-brown to white in the center, marein slightly raised and darker, dark-brown below; pycridia located mostly along the nerves, numerous on the upper surface, densely clustered, few below, spherical, regular, dark-broum, 220 - 240 mu in diam., ostiole distinct, dark-bordered, $24 \mathrm{mu}$ in diam.; conidia hyaline, ovate, pointed at one end, $4.8 .7 .2 \times 1.3-2.4 \mathrm{mu}$.

Very common whever the host was seen.

On leaves of Pithecolobium unguis- cati (L.) Benth. in Porto Rico: Desecheo, 1576 (type); Yauco, 3267 .

10. Phy llosticta pithecolobii monensis var. nov.

Spots very much like those of the species but smaller, being 3 - $5 \mathrm{~mm}$. in diam., marein darker and morc regular; pycnidia smaller, 48 - $120 \mathrm{mu}$ in diam.; conidia ovate, rounded at the ends, $4.8 \times 2.4$ mu.

On leaves of Pithecolobium unguis-cati (I.) Benth. in Porto 

Rico: Mona Island, 6137 (type).

It is perhaps significant that the host on Mona Island was of the thornless form. Though systematists do not recognize this as a distinct variety or species, the fungus upon it is distinctly different from that found on the excessively spiny Porto Rican form of host.

\section{Phyllosticta Divergen Sacc.}

Walpighia 5: 281. 1391.

On fruit of Albizzia lebbeck (I.) Benth. in Porto Rico: 1875.

This fungus is probably Phyllosticta divergens Sacc., which is reported on the leaves of this host, though there is no definite spot on the fruit as is described on the leaves. The conidia agree in length but are narrower than those of the description.

\section{Phyllosticta guanicensis sp. nov.}

Spots scattered, amphigenous, round, $1-2 \mathrm{~mm}$. in diam., yellowish-brown with a reddish-brown, slightly raised margin; pycnidia epiphyllous, few, scattered, opherical, 96 - $120 \mathrm{mu}$ in diam., sstiole distinct, $12-15.8 \mathrm{mu}$. in diam, conidia hyaline, ovate, somewhat irregular, granular, $4.8-9.6 \times 4.8 \mathrm{mu}$.

On leaves of Guilandina crista (I.) Small in Porto Rico: Guanica, 359 (type).

\section{Phyllosticta erythrinicola sp. nov.}

Spots few to nunerous, scattered, small, circular, amphigenous, sordid-white, nargin definite, regular, brom, centers falling out with age, portion of the leaf about the spot yellowish-brown; pycridia epiphyllous, scattered, dark-brorm, spherïcal, $35-72 \mathrm{mu}$ in diam., ostiole very dark, indiatinct; conidia hyaline, ovate, minute, 

$2.4-3.6 \times 1.2 \mathrm{mu}$.

On leaves of Erythrina micropteryx Poepp. in Porto Rico: Villa Alba, 110 (type); Jajome Alta, 5633; Yauco, 315\%; Mayagllez, 68.

Very common in all orts of the island, causing serious spotting of the foliage.

This species is distinct from Phyllosticta Erythrinae, which is reported on the branches of Erythrina Lithospermae. The pyenidia described are much larger, $90-180 \times 60$ - $70 \mathrm{mu}$, and lenticular in shape; the conidia were described as linear-ovate, $6-8 \times 2 \mathrm{mu}$.

14. Phyllosticta portoricensis sp. nov.

Spots amphigenous, small, grayish becoming reddiah-brown, circular to ovate, margin even, somewhat darker; pycnidia epiphyllous, few, ycattered, dark-brown, spherical, regular, darker around the border, 50 - $90 \mathrm{mu}$ in diar., ostiole distinct, 24 - $30 \mathrm{mu}$ in diam.; conidia hyaline, subspherical to ovate-oblong, 9.8 - $14.4 \times 4.8-7.2$ mu.

On leaves of Croton lucidus. I. in Porto Rico: Guanica, 325 (type).

15. Phyllosticta cissicola Speg. Anal. Hus. Nac. Buenos Aires III. 13: 332. 1910. On Cisaus sicyoides L. in Porto Rico: Vega Baja, 382; Jajome Al ta, 5633a.

16. Phyllosticta sterensil sp..nov.

Spots amphigenous, irregularly circular, $4-12 \mathrm{~mm}$. in diam., sordid-white to yellowish-bromn above, indefinite below, reddishbrown where appearing, margin distinct, irregular, dark-brown, pyc- 

nidia epiphyllous, numerous, dark-brovm, spherical to ovate, darkbordered, $96-144 \mathrm{mu}$ in diam., ostiole distinct, $24 \mathrm{mu}$ in diam.; conidia hyaline, ellipsoidal, pointed at both endo, 7.2. 34.4 X $2.4 \mathrm{mu}$.

Cn leaver of Triumfetta semitriloba Jacq, in Porto Rico: Coamo 119. (type); Villa Alba, 94

\section{Phyllosticta borinquensis sp. nov.}

Spots amphigenous, numeroug, vellowish-brown in the center. becoming darker near the margin, circular to ovate, $2-5 \mathrm{~mm}$. in diam., margin rather irregularlya angular; pycnidia epiphyllous, scattered, dark-brown, spherical, regular, 48 - 70 mu in diam., ostiole dark-bordered, $12 \mathrm{mu}$ in diam.; conidia hyaline, ova.te, 2.4 $4.8 \times 1.2-2.4 \mathrm{mu}$.

on leaves of Helicteres jamaicensis Jacq. in Porto Rico: San German, 5762, (type).

fssociated with this is one of the sphaeriaceae, with darkbrown, spherical perithecia, $96-120 \mathrm{mu}$ in diam. A mycelium of brown hyphae seems to connect the perithecia and pycnidia; asci stalked; spores eight in an ascus, septate, overe, olivaceous, 4.8.7.2. $\mathrm{X} 2.4 \mathrm{mu}$. Owing to the fact that the spores were immature, it was impossible to determine the Ecnus with any degree of certainty.

18. Phyllosticta bixina sp. nov.

Spots yellowish-brown, acattered, subcircular to irrecular. 5 - $10 \mathrm{~mm}$. in diam., numcrous, amphigenous, lighter below, often bordered by an indeterminate yellow regjon which spreads over the leaf, older portions of the spot bordered by a distinct brownishblack margin; pycnidia few, epiphyllous, spherical, dark-brown, 92 $148 \mathrm{mu}$ in dirm., ostiole distinct, dark-bordered, $12-24 \mathrm{mu}$ in diam 

conidia hyaline, ovate, $4.8-6 \times 2.4 \mathrm{mu}$.

On leaves of Bixa orellana L, in Porto Rico: Marica, 274 . (type): San German, 5794; Rosario, 4844; Mayaguez, 298; coamo, 53; Funat Santiago, 2458; Anasco, 3208; Adjuntas, 4975a.

19. Phyllosticta eupatoricola Kab. \& Bub.

Hedwigia 46: 288. 1907.

Cr. Eupatorium odoratum L, in Porto Rico: Villa AIba, 1C..

20. Phyllosticta eugeniae sp. nov.

Spots amphigenous, circular, $2-4 \mathrm{~mm}$. in diam., somewhat darker above then below, center dark-brown, surrounded by a lighter colored ring which is bordered by an even, dark, slightly elevated margin, centers falling out with age, leaf around the spot redishbrown;pycnidia more numerous on the upper surface, dark-brom, spherical to ovate, 84 - $144 \mathrm{mu}$ in diam.; conidia ovate, hyaline, granular, often remaining attached to their stalks, 9.6 - $16.8 \times 4.8-$ $6 \mathrm{mu}$.

On leaves of Eugenia buxifolia (Sw.) Willd. in Porto Rico: Mona 1 sland, 6230, (type), 6091, and 612\%.

An ascomycete is asmociated with this species. Perithecia amphifenous, dark-brown to black, spherical, regular, dark-bordered, $168-288 \mathrm{mu}$ in diam., ostiole often opening laterally; spores hyaIine, immature.

21. Fhyllosticta guareae P. Henn.

Hedwigia 41: 113. 1902.

On Guarea trichiloides L. in Porto Rico: Aqquas Buenas, 2.95. 

22. Fhyllosticta araliana sp. nov.

Spots amphigenous, yellowish-brown, circular to ovate, 4 - 8 mm. In diam., bordered by a dark-brown, regular margin; pycridia acattered, epiphyllous, spherical, 24 - $48 \mathrm{mu}$ in diam., dark-brown; conidia hyaline, ovate, slightly pointed at one end, $7.2-9.6 \mathrm{X}$ $2.4 \mathrm{mu}$.

On leaves of Dendropanax arboreum (I.) Dec. \& PI. im Porto Rico: Naricao, 755 (type).

23. Fhyllosticta sechil sp. nov.

Spcts amphigenous, irregular or confluent, varying from 2 $15 \mathrm{~mm}$. in diam., sordid-white above, darker below, margin distinct, slifhtly raised, concolorous; pycnidia epiphyllour, dark-brown, spherical, $72-96 \mathrm{mu}$ in diam., ostiole distinct, dark-bordered, $24-48$ mu in diam.; conidia hyaline, ovate, slifhtly pointed at one end, 7.2 $-9.6 \times 2.4 \mathrm{mli}$.

Cn leaves of Sechium edule (Jacq.) Sev. in Porto Rico: NayaEirez, 3357 (type).

This species differg from Phyllosticta lagenariae Passer in size and shape of conidia, these being described as oblong, rounded at the ends, $10-12.5 \times 5 \mathrm{mu}$.

24. Phyllosticta glaucispora Delacr.

Buz1. Soc. Wyc. Fr. 9: 266. 1893.

On leaves of Urechites lutea Britton in Porto Rico:

In our specimens, the spores are somewhat larger than those of the degcription, measuring $4.8-9.6 \times 2.4 \mathrm{mu}$. Phyllosticta nericola has hyaline spores, $8-10 \times 3 \mathrm{mu}$, and differs only in color and a slight variation in the size of the spore. This species is distinct from Phyllosticta Nerii in the size of sporen, those being 
(n)

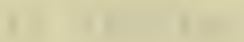

a
1) 1 1

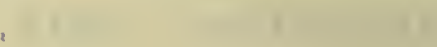

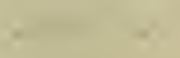
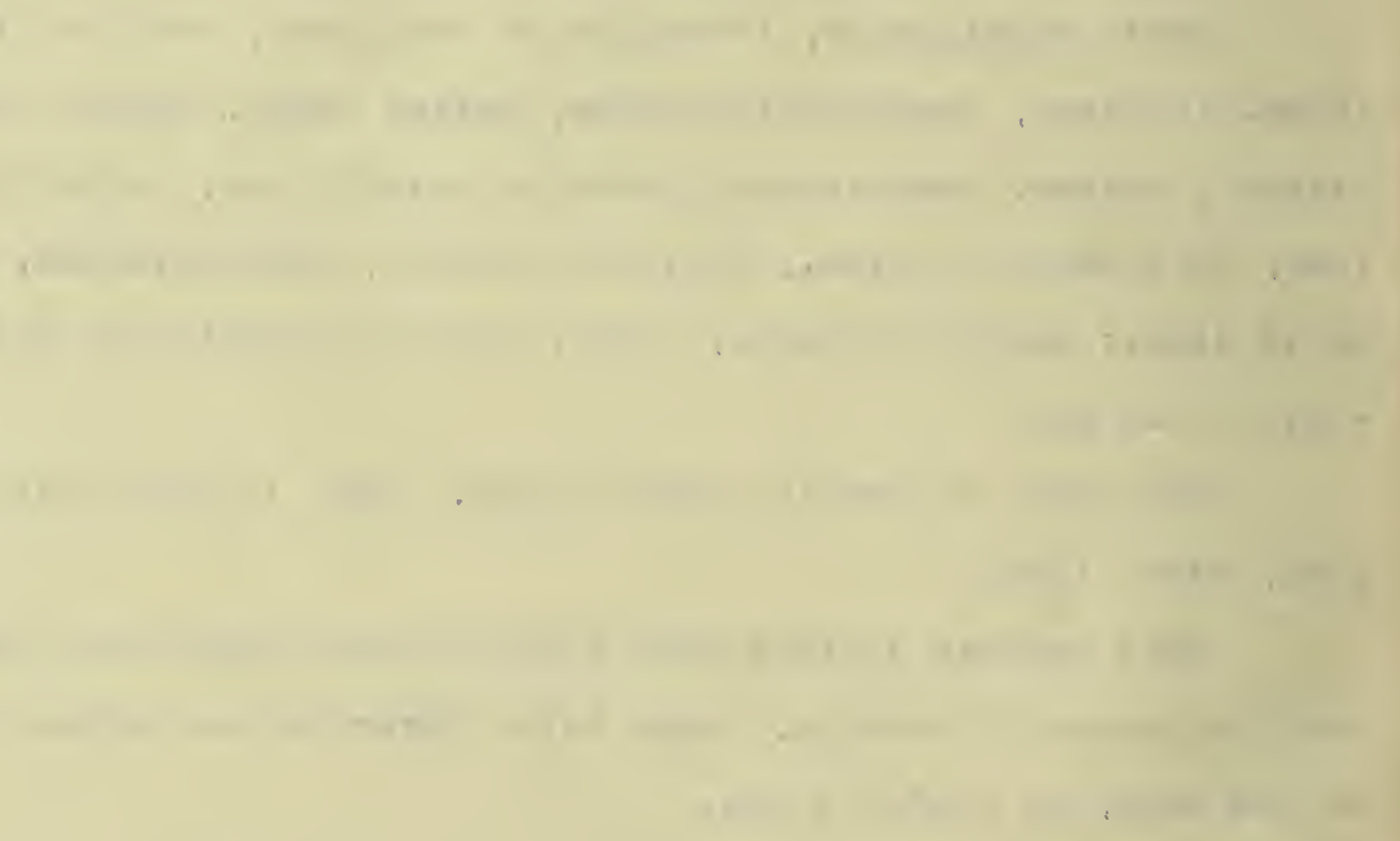
much łareer, $15-18 \times 5-6 \mathrm{mu}$.

sssociated with this is an undescribed species of Colletotrichum havine perithecia aurrounded with setae, and with hyaline, ovate spores.

25. Phyllosticta ipomoeare Ell. \& Kell.

J cur Myc. 3: 102. 1887 .

Un Exoconium repandum (Jacq.) Choiay in Porto Rico: Manati. 5313; Nayaguez, 20; Kio Piedras, 5772; Dos Bocas below Utuado, 6600.

26. Fhyllosticta pandanicola sp. nov.

Spots amphieenous, scattered over the leaf, grayish-white to light-brown, marein sliehtly darker; pycnidia located mostly along the nerves, epiphyllous, numerous, spherical to ovate, 80 - 100 X 50$60 \mathrm{mli}$, dark-brown, ostiole definite; conidir elliptical, pointed at both ends, hyaline, $96-144 \times 2.4-3.6 \mathrm{mu}$.

Or. leaves of Pandanus sp. in Porto Rico: Santurce, 240 (type)

\section{I SPECIFIC DESCRIPTIONS OF CERCOSPORA.}

1. Cercospora amaryllidis EII. \& Ev. Jour. Myc. 3: 14. 1887.

Un leaves of Hymenocallia sp. in Porto Rico: Santurce, 244; Coamo, 836 .

2. Cercospora hydropiperis (Thum.) Speg. F. Argent. Pieg. 1:191.

Helminthosporium hydropiperis Thum. W. U. n. 1087. Cercospora polyeonorum Cooke. Hedwigia 17: 39. 1878. 

On leaves of Polyeonum punctata Ill. in Porto Rico: Utuado, 4586, 4578; Coamo, 91; -.., 69; Corozal, 419; Ciales, 27; I'ayaguez, 11.54 .

\section{Cercospora lepidii Peck.}

fiep. New York State kiuseum 35:

On leaves of Lepidium sp. in Porto Rico:liona Island, 6352.

4. Cercospora phylitidis Hum.

Eul1. Torr. Eot. Club 22: 179. 1895.

On leaves of Hibiscus tiliaceus L. in Porto Rico: Rosario, 3793; Las Marias, 310; Dos Bocas below Utuado, 6618, 6564; Naricao. $3630,4797$.

5. Cercospora cajani P. Henn.

Iledwiria: 41: 309. 1902.

On leaves of Cajanus indicus Spreng. In Porto Fico: Aquas Buenas, 294; Aquada, 5100; Maricao, 1832; Anasco, 3556; Dos Bocas below Utuado, 6058, 6029, 6572; Guayanil1a, 5874; Luguillo Forest, 5608; Hormigueros, 226; lionte de Oro, 5735; Rosario, 3798.

6. Cercospora hibisci Tracy \& Earle.

Bul1. Torr. Bot. Club 22: 179. 1895.

On leaves of Hibiscus tiliaceus L. in Porto Rico: Rosario, 3793; Las kiarias, 320; Dos Bocas below Utuido, 5618; 6564; Maricao. 3630,4797 .

7. Cercospora conspicua Earle.

3u11. Hew York Bot. Gird. 3: 312. 1004. 

On Ieaves of Clcome ap. in Porto Rico: Layaguez, 6728, -. 19:

8. Cercospora bloxami B. \& Br. emend.

Ann. liat. Hist. no. 1979.

Spots spherical to ovate, 2 - $5 \mathrm{~mm}$. in diam., sordid-white to yellowish-brown, margin somemat darker; conidiophores fasciculate simple, fuscis, paler at the tips, conidial scars evident, $1-2$ septate, 75.6 - $162 \times 5.4-7.2$ mu; conidia elongate-fusiform, acuminate at one nd, 5 - 7 septate, hyaline, $50.4-144 \times 2.7-3.6$ mu.

On leaves of Brassica rapae and Brassica napi in Twyncross. 3ritain, and in Porto Rico: Bayamon, ${ }^{4} 49$; Quebradil1os, 5121.

This species differs from C. armoracias and C. brassicola in size of conidiophores and size and shape of conidia. The original description of $C$. bloxami on Brassica is very meagre, lacking in many of the essential characterg and measurements. The present emended description id drawn from the Porto Rican specimens.

9. Cercuspora portoricensis arle

Ir.uhlenbergia 1901.

On leaves of Piper hispidum Sw. in Porto Rico: Liaricao, 4802, 4792; Rosurio, 4804

\section{Cercoapora vaginae Kreuger.}

Went. Wededeel. Suiker. West-Java, p. 29. 1896.

On Saccharum in Porto Rico: 7001. Coll. Johnston.

11. Cercospora muclinae Sja.

Hedwigia 42: 136. 1903.

On leaves of Mucuna pruriens D.C. in Porto Rico: Anasco 

3535, 3601; San German, 250; Utuado, A691, 4685; I'ayaguez, 3951; Dos Bocas below Utuado, 6009, 6555; Rosario, 3779, 4704, 4806; Nonte Alli Eri110, 4779.

12. Cercospora rosicola (Paßs.) Sacc.

F. ital. t. 065 .

On leaves of Rosa cult. in Porto Rico: Maricao, 737, 3447.

4306.

13. Cercospora cassavae Ell. \& IV.

Bul1. Torr Bot. Club 22: 438. 1895.

On leaves of Casarvarp. in Porto Rico: Dos Bocas below Utuado, $655^{\prime 7}$

In our material the conidiophores are longer and sometimes septate, brow in color except for the byaline tip.

14. Cercospora densissima Špeg.

FE. ArE. novi. v. crit. p. 341. 18839.

On leaves of Sida sp. in Porto Rico: Nona Island, $6361,6354$.

15. Cercospora chamaecristae EII. \& Kell.

Jour. Myc. 4: 71. 1888.

Un leaves of Casaia occidentalis I. and Casaia alata I. in

Porto Rico: Dos Bocas below Utuado, 6054; Santurce, 269a; Anasco, 3586; kiayaguez, 1276.

In our specimens, the host $C$. occidentalis has a definite spot. The lengti of the conidiophores varies slightly rrom those of the description, being as long as $216 \mathrm{mu}$; and the conidia sre usually 3 - 5 soptate. 

16. Cercospora borinquensis $8 \mathrm{p}$. nov.

Spots definite, amphigenous, reddiah-brown, varying from aphes ical to irregular, often coaleacing to form large brown oatches on the leaves; conidiophores fasciculate, simple, septate, brown, 72 $144 \times 3.6-5.4 \mathrm{mu}$; conidia clavate, slightly curved, hyaline, 3 - 7septate, $36-54 \times 5.4-7.2 \mathrm{mu}$.

On leaves of Calopogonium orthocarpum Urban in Porto Rico: Mayaguez, 6752 (type).

17. Cercospora guanicensis sp. nov.

Spots amphigenous, spherical to ovate, yellow to ereenishbrown above, reddish-brom below: conidiophorea densely fasciculate, septate, unbranched, $76-96 \times 4.8 \mathrm{mu}$; conidia oblong-cylindric, subhyaline, slightly curved, 3 - 6 septate, eranular, 39.6 - 96 X 3.6 $7.2 \mathrm{mu}$.

On leaves of Guilandina crista in Porto Rico; Guanica, 6845. 6840 (type).

18. Cercospora stevensii sp. nov.

Spots amphigenous, reddish-brow above, black below, I - 2 mm. in dian.: conidiophores densely fasciculate, simple, cylindrical, brown, septate, often peculiarly rtwisted; conidia hyaline, clavate, slikhtly curved, 3 - 5 septate, granular, $32.4-72 \times 3.6-6.2 \mathrm{mu}$. On leaves of Andira $3 p$. in Porto Rico: Dos Bocan belon Utuado, 6540,60083 (type).

19. Cercospora bradburyae sp. nov.

Snot amphigenous, varying from spherical, $1-2 \mathrm{~mm}$. in diam. to diffuse, yellowish-brown to maty-red; conidiophores densely fas- 

ciculate, simple, fuscis, $12-36 \times 3.6-4.8 \mathrm{mu}$; conidia elongatecylindrical, hyaline, $5-7$-septate, $48-96 \times 2.4-3.6 \mathrm{mu}$.

On leaves of Bradburya pubescens in Porto Rico: Wayaguez, 6296 3930;479; Luguillo Forest, 5609; Dos Bocas below Utuado, 6588; San Eerman, 5790, 5833, 5785: Guayama, 5112; Jayuya, 446a; Hormigueron, 225a; Caba Rojo, 6482; Rosario, 446 (type).

\section{Cercospora maricaoensis 3p. not.}

Spots diffuse, brown, scattered over the leaf, amphigenous, more numerous above than below; conidiophores lookely fagciculate, of ten brancied, septite, pale olivaceous, 54 - 144 X $5.4-7.2 \mathrm{mu}$; conidia oblong-cylindrical, hyaline, sometimes slightiy curved, 3 5 septate, $36-31 \times 3.6-5.4 \mathrm{mu}$.

On leaves of Teramnus uncinatus (I.) Sw. in Porto Rico: Maricao 764; Dos Bocas below Utuado, 6554 (type); ...., 5815; Caha Rojo, 2271.

\section{Cercospora malachrae yp. nov.}

Spota scattered, amphigenous, soherical, 2 - $5 \mathrm{~mm}$. in diam., centerg white, surrounded by a black, slightly elevated margin, a portion of the leaf about the spot reddish-purple to purpliah-black, often large areas infected; conidiophores fasciculate, dark-brown, few-septate, $63-144 \times 3.6-5.4 \mathrm{mu}$; conidia hyaline, clavate, 90 $108 \times 3.6 \mathrm{mu}$.

On leaves of Malachra rotundifolia in Porto Rico: San Sebas. tian, 5199(type); Ponce, 5003; Guanica, 338a; Yauco, 3246; San German, 5840; Vega Baja, 431, 381. 
$x^{3} \cdot 4$

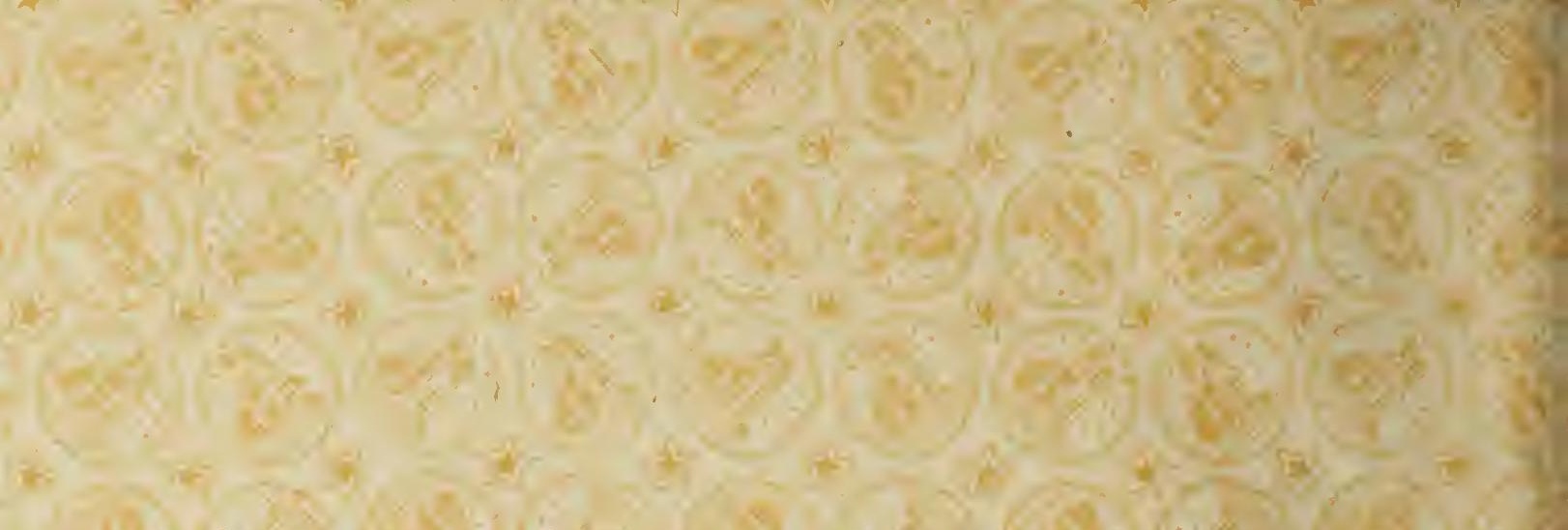

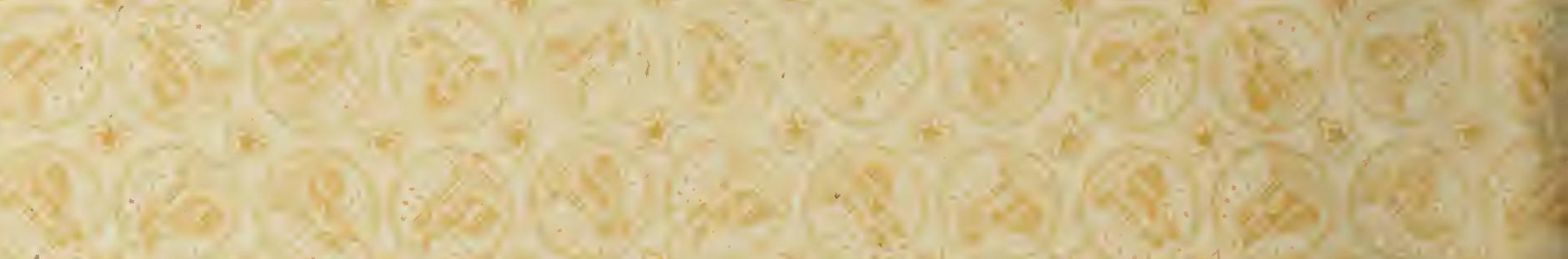

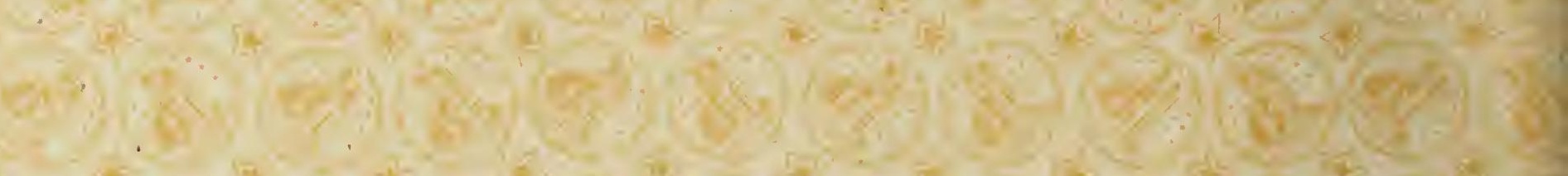

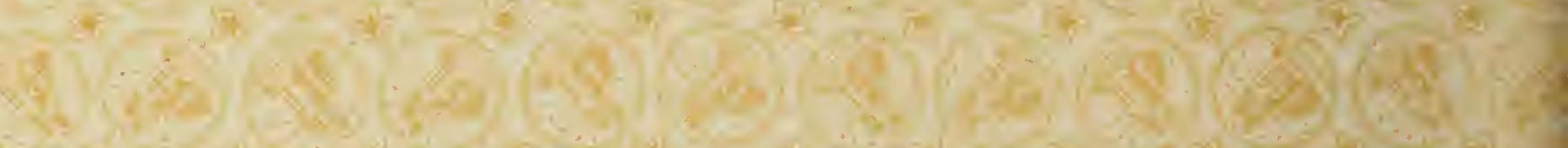

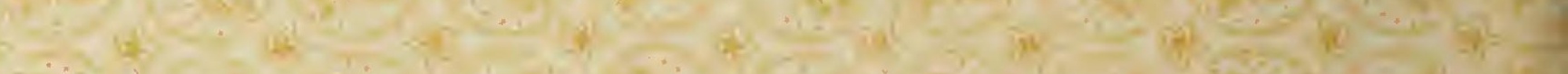

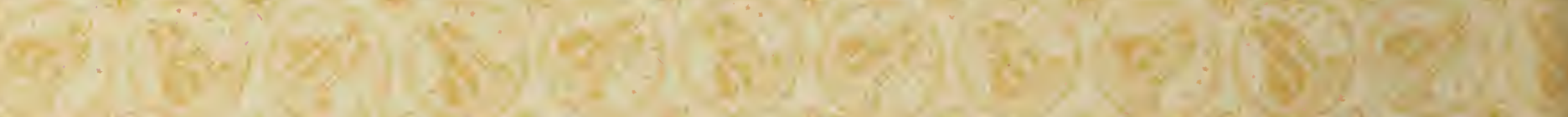

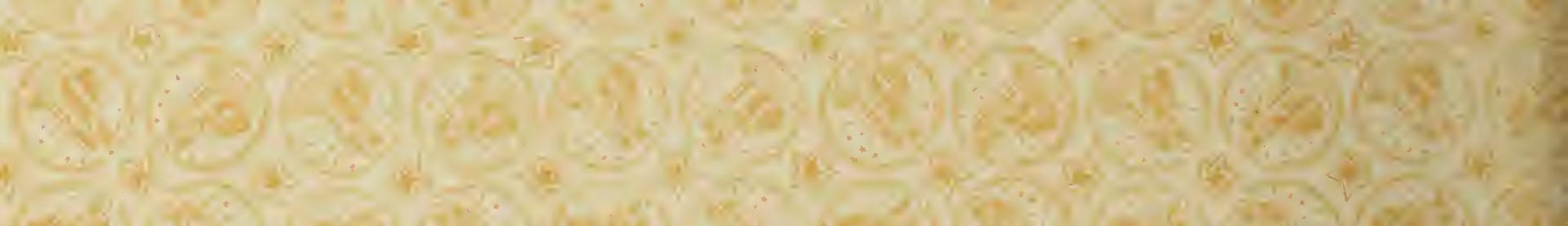

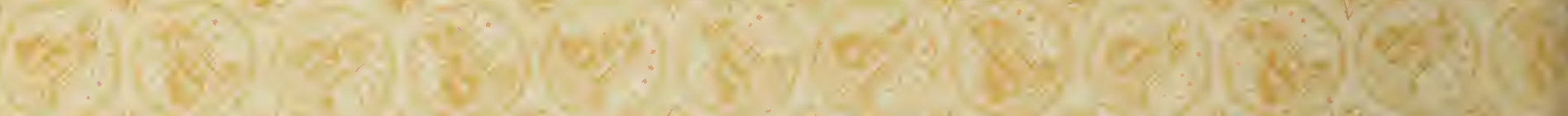

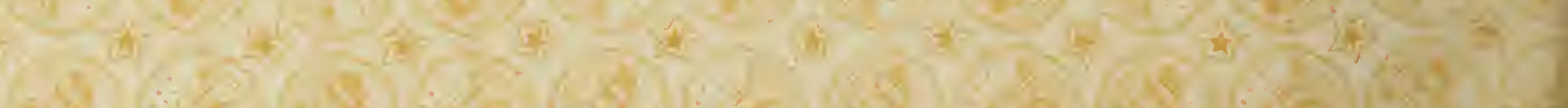

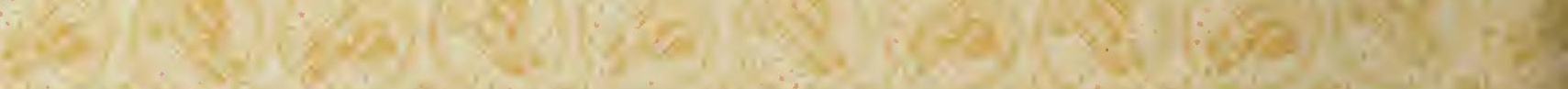

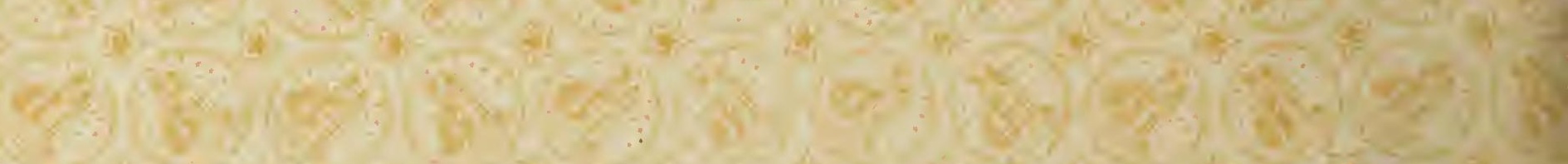

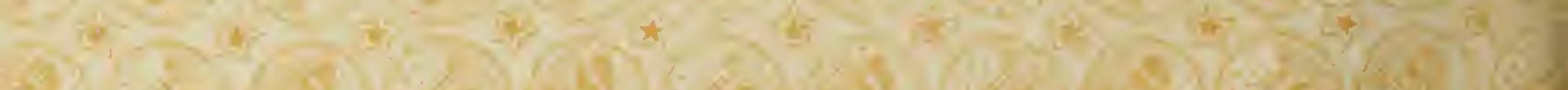
Q (2) wa

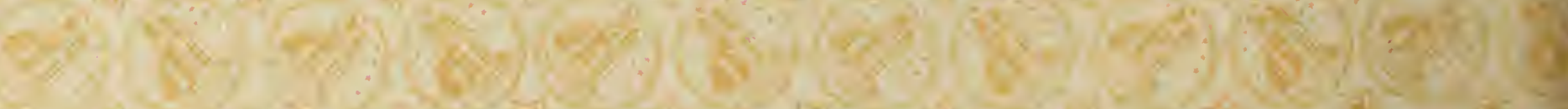

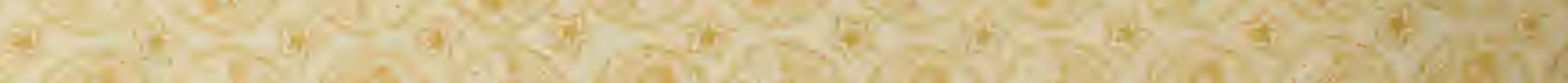

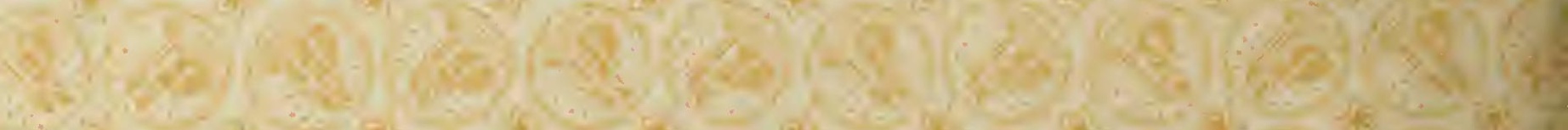

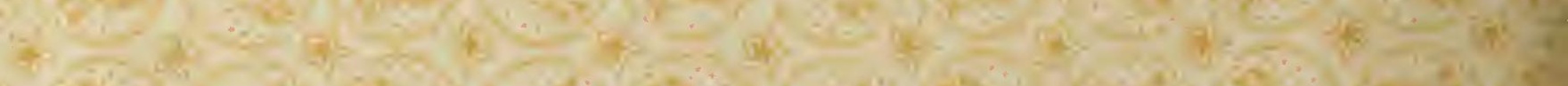

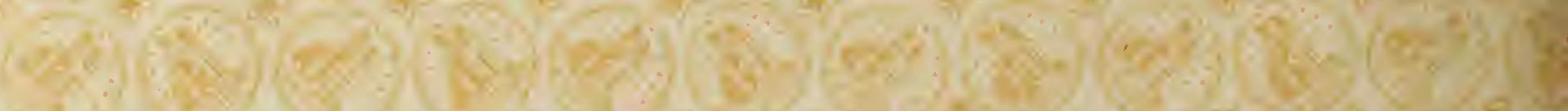
20 (2) 



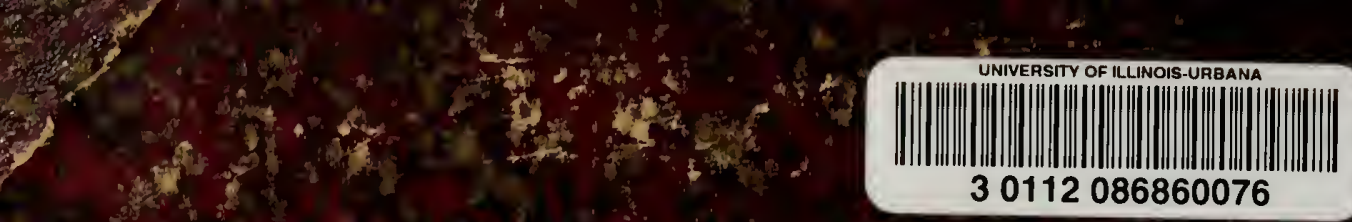

